ña, fue realizada por José Ignacio de la Cerda y se conserva en el ex convento de Acolman. Del mismo autor, hay otra en las galerías Windsor de la ciudad de México. Hay una más que no sabemos dónde se encuentra hoy día, pero que fue ofrecida en venta al Museo de la Basílica hacia I984. Tenemos además una versión en lámina que pertenece al Museo Nacional de Arte (Munal) y un grabado de 1829 realizado por Francisco Gordillo, hoy parte de la colección de Isaac Backal.

La existencia de estas siete obras, todas incluidas en este volumen con una gran calidad de impresión, muestra cómo la reproductibilidad de un mismo motivo iconográfico puede adaptarse a distintos materiales y tamańos. Más aún, tanto la lámina del Munal como el grabado de Backal permiten a Cuadriello aventurarse en el fascinante terreno de los modos en que esta iconografía única de la Virgen del Carmen estaba expuesta en los altares, pues en ambas imágenes se muestra a María en un marco arquitectónico, escoltada por esculturas de las virtudes teologales y cardinales. Esto es sugerente pues muestra el contexto visual donde la imagen y el culto al que alude se propagaron, para recordar que cada copia estaba hecha para cumplir con funciones devocionales concretas.

El juego de reflejos es siempre infinito. Al ser necesario limitarlo, tan sólo queda invitar al lector a realizar su propia danza de imágenes interminables. Si se anima y se adentra en las páginas de este volumen, sin duda aprenderá mucho. No sólo sobre el culto mariano y la historia carmelita sino también sobre las reacciones de los novohispanos ante hechos de relevancia global como la Revolución francesa e incluso un poco de la historia arquitectónica de la ciudad de Morelia a través del peculiar palacio del conde Escandón.
Aprenderá también a leer imágenes sacras tomadas de la mano de un fraile del siglo XviıI y de un historiador del arte contemporáneo y dará sentido a la historia de este manuscrito que, tras dos siglos de espera, finalmente llegó a las imprentas. Pese a que las imágenes de este juego de espejos estén llenas de mácula y no sean eternas como aquello a lo que refieren, quedan, pues, para su entendimiento y disfrute.

\section{\$ \\ Patrocinio, monarquía y poder: el glorioso patriarca señor san Joseph en el Perú virreinal Irma Barriga Calle}

Lima, Pontificia Universidad Católica del Perú, Instituto Riva-Agüero, 20 Iо

por

MÓNICA PULIDO ECHEVESTE

El culto al patriarca san José constituyó un lugar común en el imaginario de la sociedad novohispana, donde españoles, indios y castas encontraron consuelo y protección ante las calamidades naturales como rayos y tormentas o ante momentos arduos como la viudez o el tránsito a la muerte. ${ }^{\mathrm{I}}$ La devoción por el esposo de María gozó de gran prominencia desde el siglo Xvi, cuando el Primer

I. David Freedberg, El poder de las imágenes, Madrid, Cátedra, I992, pp. 69-73. 
Concilio Provincial mexicano lo juró como patrón y abogado de toda la Nueva España, por "la gran devoción" que indios y españoles le profesaban. El reconocimiento -impulsado por los franciscanos- como intercesor en la evangelización de los naturales dio lugar en el siglo Xvir a un discurso que lo situaba como paradigma político del buen gobernante. ${ }^{2}$ El libro de Irma Barriga Calle da cuenta del desarrollo del culto josefino en el virreinato del Perú, tal como un fenómeno que comparte muchos de sus elementos con el caso novohispano, pero que sin duda tuvo una vida propia.

Quizá uno de los atractivos más importantes del estudio del culto de san José es la posibilidad de adentrarse, a partir de su análisis en el estudio de la vida social, en los más variados aspectos del imaginario político e identitario. Fue justamente como historiadora de las mentalidades y de las actitudes ante la muerte como Irma Barriga llegó a interesarse en la figura del santo patriarca. Las fuentes documentales que dan constancia de la devoción revelan simultáneamente la naturaleza de las relaciones de poder entre individuos y corporaciones - como el obispo, el cabildo eclesiástico, el ayuntamiento, los gremios y las cofradías en la organización de las festividades-, y el apoyo o la censura de los argumentos teológicos en que se fundaba el culto. Las cofradías son asimismo un observatorio perfecto donde convergieron los estratos de la sociedad y donde intereses económicos y privilegios sociales fueron continuamente negociados.

2. Jaime Cuadriello, "San José en tierra de gentiles: ministro de Egipto y virrey de las Indias", Memoria, núm. I, I989.
La riqueza de las lecturas simbólicas detrás del culto de san José ha sido posible gracias a la amplitud de las fuentes utilizadas por la autora: tratados, testamentos, crónicas, constituciones y cuentas de cofradías, sermones panegíricos, actas de cabildo, devocionarios y autos sacramentales que junto con las imágenes y las iglesias, ermitas y capillas hacen notoria la amplitud que alcanzó la devoción. En esta variedad de documentos se hace visible la multiplicidad de factores sociales, religiosos y políticos que, tanto en las principales ciudades como en el campo, propiciaron la promoción sostenida del culto desde todos los estratos de la sociedad.

La diversidad de los actores y las estrategias que siguieron para promover la devoción josefina introduce algunas interrogantes que resultan esenciales en el estudio del surgimiento y desarrollo del culto a los santos, en especial al tratarse de una devoción tan extendida y generadora de nuevos repertorios y discursos. ¿Cuál es el móvil original de los cultos? ¿Son, acaso, resultado de una imposición vertical con fines políticos, de la orquestación de un obispo o un tratadista devoto y visionario o de la respuesta piadosa de un pueblo que recurre al santo en busca de auxilio? ¿Cuánto, pues, tiene que ver en ello la iniciativa local, o son los cultos respuestas alternativas? $\mathrm{Ni}$ aun en los casos de patrocinios mejor estudiados o documentados es fácil responder a esta interrogante. El caso peruano no es la excepción, pero ofrece un panorama de amplia complejidad al ponderar, en primer término, los efectos que desde la Iglesia universal tuvo el Concilio de Constanza (I4I6) en la dignificación del personaje de san José, así como su nacimiento, como santo moderno, a partir del lugar privilegiado de que gozó en la vida mística de 
santa Teresa de Ávila; en segundo término, su aceptación por parte de la monarquía española como modelo ejemplar para los fieles, figura secular y cohesionadora, $y$, finalmente, el apoyo de las órdenes regulares y el establecimiento de las cofradías como la base social que mantuvo activo y floreciente el culto, incluso después de la independencia de Perú (en I828, el clamor popular obligó al Congreso Constituyente a restituir la celebración anual de la fiesta).

El estudio está estructurado en tres capítulos. El primero brinda al lector un perfil introductorio que da cuenta de la invención "barroca" del santo por contraste con la escasa importancia que tenía para la Iglesia medieval. Así se destaca el quiebre entre la figura apocada del anciano y torpe José y el joven santo patriarca del siglo XviII. La autora se adentra también en el interesante proceso de construcción de la historia del santo, su estatuto teológico y el éxito de su culto como patrono y abogado de múltiples oficios y causas, todo como un fenómeno de enorme amplitud para la Iglesia hispánica. Si bien este proceso ya ha sido objeto de estudio de otros autores, vale la pena el acercamiento que hace Irma Barriga desde los evangelios apócrifos hasta los tratados de santa Teresa de Jesús, en un diálogo entre los procesos compartidos por la Iglesia universal y la monarquía que dominaba al "mundo hispánico".

El segundo capítulo se dedica al desarrollo del culto josefino en Perú. Es, sin duda, la aportación más sustancial gracias a la visión de la autora y a la riqueza de las fuentes que lo sustentan. Tras el análisis del asentamiento de las cofradías, el reconocimiento de la festividad y la recepción que tuvo la obra de santa Teresa de Ávila en el virreinato, Barriga se centra en las obras de tres tratadistas - el je- suita Juan de Alloza, el dominico Joseph de Pastrana y el jesuita Pedro de Torres-, publicadas en 1652, I696 y I7 Io, respectivamente. Sin estos volúmenes sería imposible entender el desarrollo tanto del culto como de la iconografía de las imágenes josefinas surgidas en Perú. Estas tres obras manifiestan la existencia de una tradición josefina consciente y sostenida, pues, a pesar de que la naturaleza de cada una es diferente, tanto Pastrana como Torres glosan sin desperdicio a sus antecesores. Vale la pena hacer un recorrido por los argumentos de estos autores, dado que en ellos se encuentra la clave del culto josefino de las altas esferas de la cultura religiosa peruana.

La obra de Alloza se autorizaba a sí misma con la fama de santidad que rodeaba al autor, aumentada por su estrecha relación con la figura de otro jesuita, Francisco del Castillo, gran promotor de san José en el Perú a principios del siglo XVII, quien también gozó de fama de santo. Alloza hacía hincapié en dos aspectos fundamentales: la pobreza de san José frente a la nobleza de su linaje y la devoción de la Sagrada Familia como Trinidad terrena que se correspondía con la celestial. Según Irma Barriga, el acento en el carácter afectivo, humano y familiar que distigue a la obra de Alloza describe el tipo de devoción surgido en el siglo xviI, centrado en la relación paternal y emotiva entre el padre y el niño y en "el juego de dones y contra-dones" que no sólo explican la relación de los fieles con su patrono e intercesor, sino que además resultaban fundamentales en las relaciones políticas y sociales entre jerarquías.

A su vez, la obra del dominico Joseph de Pastrana obedecía a un momento en que la devoción se había expandido a todos los sectores de la sociedad, como recurso y refugio 
ante las muchas causas y necesidades que aquejaban a la población. El autor buscaba infundir entre sus lectores una religiosidad más exaltada, promoviendo la devoción de los "Siete dolores y gozos de san José" por medio de una narración plena de detalles sobre la vida del patriarca, animada por una suerte de diálogos inventados y acompañada de oraciones y devocionarios. En la pluma de Pastrana, el acento cae menos en la parte afectiva que en el carácter taumatúrgico del santo, insistiendo en su gran poder y en el amplio espectro social de sus devotos y de aquellos que habían sido favorecidos por sus milagros en las más variadas ocasiones. Los abundantes testimonios que logró recoger la autora sobre imágenes josefinas que se movían, sudaban o lloraban, como prueba de la "presencia" divina que mostraba su favor ante una comunidad, forman un corpus verdaderamente interesante, pues la mayor parte de los estudios que se han realizado sobre imágenes animadas se refieren a figuras de Cristo o María.

Finalmente, la obra de Pedro de Torres resulta especialmente sugerente por el atrevimiento desmedido de sus elogios y alabanzas a la figura del patriarca, al grado de haber sido prohibida in totum por el Santo Oficio de Lima. De prosa barroca, con un uso recurrente de metáforas y símbolos, llevando — según el juicio de la autora - al extremo el uso de la exégesis en las prefiguraciones del Antiguo Testamento como "anticipos y sombras" del santo y abundando en la interpretación del Apocalipsis para explicar la historia de la salvación, Torres encumbró la figura de san José desde su carácter de "justo" hasta la majestad como "rey de reyes", cabeza del cuerpo místico de los santos y émulo del padre, elevando su dignidad al grado de la Trinidad Celestial e incluso por encima de María, por lo que naturalmente sería considerado fuera del canon.

El análisis de la obra de Torres abre el camino para descubrir el peso político que tuvo el culto josefino. La devoción de los monarcas españoles por san José era bien conocida, en especial la de Carlos II quien en I678 emitió una real cédula reconociéndolo como "Patrono de España y sus dominios”. La disposición fue confirmada por el breve de Inocencio XI que otorgó indulgencia plenaria para su fiesta del I9 de marzo; sin embargo, el perjuicio que podía sufrir la devoción de Santiago como patrono del reino obligó al monarca a revocar su decisión. Detrás del conflicto obviamente se perfilaban razones políticas. El paralelismo que se establecía entre José "virrey de Egipto" como prefiguración de san José "virrey de Indias" lo convertía en el paradigma del buen gobernante. Al igual que los virreyes, san José había recibido su poder de una majestad superior de la que era ministro. La vara florida del santo era en sí misma el cetro de donde emanaba su potestad, creando una imagen de grandeza sustentada en un discurso de incontenible potencial político.

En el tercer capítulo, dedicado a la iconografía, vemos cómo los discursos hasta aquí presentados adquirieron una dimensión visual. ${ }^{3}$ El catálogo sigue el orden del proceso en que la figura de san José se independizó de las escenas de la vida de Cristo y la Virgen para alcanzar un lugar propio en las representaciones de san José con el Niño, los patroci-

3. Héctor Schenone propuso una clasificación de la iconografía josefina con abundantes ejemplos del arte peruano, aunque sin considerar la relación directa entre las imágenes y los discursos. Héctor Schenone, Iconografía del arte colonial. Los santos, vol. 2, Buenos Aires, Fundación Tarea, I 992. 
nios, la glorificación y las escenas del tránsito asociadas a su tutela sobre la buena muerte. La propuesta respondía originalmente al proyecto de una exposición y aunque como sistematización de una tipología iconográfica el orden no es siempre claro, la comprensión del fenómeno político y de las mentalidades permitió a la autora hacer un acertado análisis de la evolución de la iconografía del arte andino y limeño, desde las imágenes evangelizadoras hasta las alegorías políticas que representaban una institución.

Si bien la dimensión política de las alegorías es uno de los puntos más sólidos y atractivos del análisis de Barriga, el carácter sagrado de la misma escultura devocional pasa prácticamente inadvertido. Las imágenes de san José y el Niño son referidas únicamente desde sus características plásticas o artísticas, dejando de lado que se trataba, en especial las esculturas de talla, de imágenes con "poderes", propiedad de iglesias y cofradías, unidas por fuertes vínculos a los espacios locales y sus comunidades. ${ }^{4}$ No todas las imágenes eran consideradas igual de milagrosas, por lo que el éxito de las cofradías dependía de la fama de cada una en particular. Se extraña, por lo tanto, el vínculo entre las corporaciones descritas en el segundo capítulo y la sinergia con sus imágenes.

Lo anterior no demerita el valor del estudio de Irma Barriga. El enfoque monográfico dado al examen del culto de san José revela la riqueza del universo cultural en que se desarrolló el corpus de obras pictóricas y escultóricas sobre el santo. La mirada con que la autora se acerca a las imágenes, fuera del ámbito del análisis estilístico, sitúa a la producción josefina en una dimensión de justa complejidad y tiende puentes para el diálogo con sus símiles novohispanos. Como puede apreciarse a lo largo del libro, la vida del culto josefino en el virreinato del Perú se erigió como un espejo del culto en la Nueva España. Las políticas monárquicas incluyeron a ambos virreinatos en una misma dinámica y en consecuencia, aunque las diferencias culturales dieron a cada territorio un perfil propio, generaron también respuestas semejantes y un imaginario social, político y religioso compartido. La aproximación de Irma Barriga al culto de san José en Perú resulta de especial interés para ser reconsiderado por la historia del arte novohispano.
4. Gerhard Wolf, "Icons and Sites", en Images of the Mother of God. Perceptions of the Theotokos in Byzantium, Aldershot, Ashgate, 2005, p. 35. 